Wahyudin, A $\cdot$ Ruminta $\cdot$ D.C. Bachtiar

\title{
Pengaruh jarak tanam berbeda pada berbagai dosis pupuk organik terhadap pertumbuhan dan hasil jagung hibrida P-12 di Jatinangor
}

\section{Effect of different plant spacing with various dosages of organic fertilizer on growth and yield of maize hybrid P-12 in Jatinangor}

Diterima : Januari 2015/Disetujui : Februari 2015 / Dipublikasikan : Maret 2015

CDepartment of Crop Science, Padjadjaran University

\begin{abstract}
The objective of this experiment was to get the best of plant spacing and dosage of organic fertilizer from sheep manure which gave the best effect on growth and yield of P-12hybrid maize. The experiment was conducted in Ciparanje Experimental Land, Faculty of Agriculture, Padjadjaran University, Jatinangor, Sumedang, with altitude \pm 750 meter above sea level, from March to July 2013. The experimental methods used Randomized Block Design that consisted of 9 treatments with 3 replications. The treatments were : spacing of $75 \times 25 \mathrm{~cm}+2 \mathrm{t} /$ ha manure, spacing of $75 \times 25 \mathrm{~cm}+1 \mathrm{t} /$ ha manure, spacing of $75 \times 25 \mathrm{~cm}+3 \mathrm{t} /$ ha manure, spacing of $75 \times 40$ $\mathrm{cm}+2 \mathrm{t} /$ ha manure, spacing of $75 \times 40 \mathrm{~cm}+1$ $\mathrm{t} /$ ha manure, spacing of $75 \times 40 \mathrm{~cm}+3 \mathrm{t} / \mathrm{ha}$ manure, spacing $80 \times 20 \mathrm{~cm}+2 \mathrm{t} /$ ha manure, spacing of $80 \times 20 \mathrm{~cm}+1 \mathrm{t} /$ ha of manure, and spacing of $80 \times 20 \mathrm{~cm}+3 \mathrm{t} /$ ha manure. The result showed had an effect on Leaves Area Index, number rows of seeds per cob, weight of driedseeds in each plot, yield in hectare, and harvest index. Treatment of spacing $75 \times 25 \mathrm{~cm}+$ $1 \mathrm{t} /$ ha manure gave $7.66 \mathrm{t} /$ ha of yield and that better than spacing of $75 \times 25 \mathrm{~cm}+3 \mathrm{t} / \mathrm{ha}$ manure.
\end{abstract}

Keywords : Corn · Plant spacing · Sheep manure

Sari Penelitian ini bertujuan untuk memperoleh jarak tanam dan dosis pupuk organik kandang domba yang memberikan pengaruh terbaik terhadap pertumbuhan dan hasil tanaman jagung Hibrida P-12. Percobaan dilaksanakan di

\footnotetext{
Dikomunikasikan oleh Tati Nurmala

Wahyudin $\mathrm{A}^{1} \cdot$ Ruminta $^{1} \cdot$ D.C. Bachtiar ${ }^{2}$

${ }^{1}$ Staf Pengajar Program Studi Agroteknologi Fakultas

Pertanian Unpad

2 Alumni Fakultas Pertanian Unpad

Korespondensi: agus.wahyudin@unpad.ac.id
}

Kebun Percobaan Ciparanje, Fakultas Pertanian, Universitas Padjadjaran, Jatinangor, Kabupaten Sumedang, dengan ketinggian tempat \pm 750 meter di atas permukaan laut, dari bulan Maret sampai Juli 2013. Metode percobaan yang digunakan adalah Rancangan Acak Kelompok yang terdiri dari 9 perlakuan dan diulang tiga kali. Perlakuannya adalah sebagai berikut : Jarak tanam $75 \times 25 \mathrm{~cm}+2 \mathrm{t} /$ ha pupuk kandang, jarak tanam $75 \times 25 \mathrm{~cm}+1 \mathrm{t} /$ ha pupuk kandang, jarak tanam $75 \times 25 \mathrm{~cm}+3 \mathrm{t} /$ ha pupuk kandang, jarak tanam $75 \times 40 \mathrm{~cm}+2 \mathrm{t} /$ ha pupuk kandang, jarak tanam $75 \times 40 \mathrm{~cm}+1 \mathrm{t} /$ ha pupuk kandang, jarak tanam $75 \times 40 \mathrm{~cm}+3 \mathrm{t} /$ ha pupuk kandang, jarak tanam $80 \times 20 \mathrm{~cm}+2 \mathrm{t} /$ ha pupuk kandang, jarak tanam $80 \times 20 \mathrm{~cm}+1 \mathrm{t} /$ ha pupuk kandang, dan jarak tanam $80 \times 20 \mathrm{~cm}+3 \mathrm{t} /$ ha pupuk kandang. Hasil percobaan menunjukkan terdapat pengaruh terhadap Indeks Luas Daun, Jumlah Baris Biji per tongkol, Bobot biji pipilan kering per petak, bobot biji pipilan kering per hektar, dan Indeks Panen. Perlakuan jarak tanam 75 x $25 \mathrm{~cm}$ $+1 \mathrm{t} /$ ha pupuk kandang memberikan hasil lebih baik dari perlakuan jarak tanam $75 \times 25 \mathrm{~cm}+$ 3t/ha, yaitu 7,66 t/ha, tetapi tidak berbeda dengan perlakuan lainnya.

Kata kunci : Jagung · Jarak tanam · Pupuk kandang domba

\section{Pendahuluan}

Jagung (Zea mays L.) merupakan salah satu komoditas strategis dan memiliki potensi yang sangat besar dalam perekonomian dan kebutuhan pangan, pakan, bahan baku industri, dan kerajinan tangan. Menurut Zubachtirodin dkk (2007), pada tahun 2000 kontribusi jagung dalam perekonomian nasional mencapai $\operatorname{Rp} 9,4$ trilyun 
dan pada tahun 2003 meningkat menjadi Rp 18,2 trilyun.

Berdasarkan data BPS (2014), pada tahun 2009-2013, rata-rata luas areal panen jagung di Indonesia sekitar 3,9 juta ha/tahun dan terus menurun dengan laju penurunan 1,82 \% per tahun. Luas areal pertanaman jagung menduduki urutan kedua setelah padi sawah. Jika dibandingkan dengan komoditas padi, luas pertanaman jagung hanya sebesar $30 \%$ (Zubachtirodin dkk., 2007).

Produktivitas jagung di Indonesia pada tahun 2009-2013 masih sangat rendah, dengan rata-rata 4,58 t/ha, namun cenderung meningkat dengan laju 3,36 \% per tahun. Masih rendahnya produktivitas menggambarkan bahwa penerapan teknologi produksi jagung belum optimal. Pada tahun 1990-2006, rata-rata laju pertumbuhan produksi jagung di Indonesia 4,17 \% per tahun (Zubachtirodin dkk., 2007). Menurut BPS (2014), pada periode 2009-2013, produksi jagung di Indonesia rata-rata 18,3 juta ton dengan ratarata laju pertumbuhan 2,27\% per tahun. Hal ini menunjukan bahwa produksi terus menurun dalam kurun waktu 20 tahun terakhir.

Menurut Balai Penelitian Tanaman Serealia (2014), volume impor jagung tahun 2011 hingga 2013 terus meningkat, bahkan pada tahun 20122013 peningkatan impor mencapai 72,3 \%. Besarnya impor komoditas jagung ini mengindikasikan bahwa produksi jagung di Indonesia masih belum memenuhi kebutuhan konsumen.

Menurut Bakhri (2007), usaha peningkatan produksi jagung di Indonesia dapat dilakukan melalui dua program utama yakni: (1) Ekstensifikasi (perluasan areal) dan (2) intensifikasi (peningkatan produktivitas). Dalam peningkatan hasil tanaman jagung juga diperlukan benih yang berkualitas, sehingga diperlukan varietas jagung yang memiliki sifat unggul (Pusat Penelitian dan Pengembangan Tanaman Pangan, 2012). Kualitas biji yang baik akan menjamin harga jual yang tinggi, sehingga pendapatan petani akan maksimal (Hariyadi, 2013)

Pengaturan populasi tanaman dengan mengatur jarak tanam yang sesuai merupakan salah satu program intensifikasi untuk meningkatkan laju produksi tanaman. Secara tidak langsung, pengaturan jarak tanam dapat mempengaruhi intensitas cahaya matahari yang dapat diterima tanaman. Cahaya matahari merupakan sumber energi bagi proses fotosintesis.
Selain pengaturan jarak tanam, faktor kesuburan tanah merupakan salah satu faktor produksi yang mempunyai sumbangan cukup besar (sekitar $55 \%$ ) terhadap keberhasilan produksi (Deptan, 2013). Pemberian pupuk organik merupakan salah satu upaya dalam meningkatkan kesuburan tanah.

Menurut Sutanto (2002), pemberian pupuk organik, selain dapat meningkatkan produksi dan produktivitas tanaman, juga akan memperbaiki kemampuan tanah menyimpan air, meningkatkan kapasitas infiltrasi dan memperbaiki drainase tanah. Salah satu bahan organik seperti pupuk kandang domba paling sering digunakan petani sebagai asupan bahan organik untuk tanah dan tanaman. Menurut Adianto (1993), pupuk organik yang berasal dari kotoran hewan disebut sebagai pupuk kandang. Unsurunsur hara makro seperti nitrogen $(\mathrm{N})$, fosfor $(\mathrm{P})$, dan kalium $(\mathrm{K})$ membuat yang terkandung dalam pupuk kandang dapat berperan penting untuk pertumbuhan dan perkembangan tanaman.

Menurut Las dan Setyorini (2010), pupuk kotoran domba mengandung unsur $\mathrm{N}, \mathrm{K}$, dan Ca yang lebih tinggi dibanding kotoran sapi, sedangkan kandungan $\mathrm{P}$ pada kotoran domba masih tergolong rendah. Hasil penelitian dari Balai Penelitian Ternak (Balitnak) Bogor (2010), kotoran ternak domba mengandung bahan kering dan nitrogen berturut-turut $40-50 \%$ dan $1,2-2,1 \%$, bergantung pada komposisi pakan. Penambahan atau efisiensi pupuk anorganik dapat menghasilkan kombinasi yang lebih baik untuk budidaya tanaman jagung.

Maka dari itu perlu dilakukan penelitian untuk meningkatkan hasil tanaman jagung dengan pengaturan jarak tanam dan penambahan bahan organik berupa pupuk kandang kotoran domba di lahan Inceptisols Jatinangor.

\section{Bahan dan Metode}

Percobaaan dilakukan di kebun percobaan Ciparanje, Fakultas Pertanian Universitas Padjadjaran, Jatinangor, Kabupaten Sumedang, Jawa Barat dengan ketinggian tempat \pm 750 meter di atas permukaan laut dan tanah Inceptisols, tipe curah hujan C3 menurut Oldeman (1975). Percobaan ini dimulai dari Maret-Juli 2013. Bedasarkan hasil analisis, nilai $\mathrm{pH}$ tanah yaitu 6,12 dengan rata-rata suhu

Wahyudin, dkk: Pengaruh jarak tanam berbeda pada berbagai dosis pupuk organik terhadap pertumbuhan dan hasil jagung hibrida P-12 di Jatinangor 
harian selama percobaan berlangsung berkisar antara $22,23-26,47^{\circ} \mathrm{C}$.

Bahan yang digunakan pada percobaan ini antara lain adalah Benih Jagung Hibrida Pioneer-12, Pupuk kotoran domba, Pupuk urea (45\%), Pupuk SP-18 (18\% $\left.\mathrm{P}_{2} \mathrm{O}_{5}\right), \mathrm{KCl}\left(60 \% \mathrm{~K}_{2} \mathrm{O}\right)$, Insektisida Curacron, Fungisida Dithane, dan Furadan 3G. Alat yang digunakan pada percobaan ini antara lain adalah cangkul, tugal, kored, alat penyiraman, tali rapia, meteran, pisau, seng, cat, label, plastik, jangka sorong, timbangan analitik, timbangan, oven listrik, leaf area meter dan alat tulis.

Metode percobaan yang digunakan adalah Rancangan Acak Kelompok (RAK), terdiri dari sembilan perlakuan dan diulang tiga kali untuk tiap perlakuan. Plot percobaan berukuran $3 \mathrm{~m} \mathrm{x}$ $4 \mathrm{~m}$. Perlakuan yang diberikan adalah dengan pemberian berbagai perlakuan jarak tanam dan dosis pupuk kandang domba dengan rincian perlakuan sebagai berikut: $\mathrm{A}=$ kontrol (Jarak tanam $75 \times 25 \mathrm{~cm}+2 \mathrm{t} /$ ha pupuk kandang), B = Jarak tanam $75 \times 25 \mathrm{~cm}+1 \mathrm{t} /$ ha pupuk kandang, $\mathrm{C}=$ Jarak tanam $75 \times 25 \mathrm{~cm}+3 \mathrm{t} /$ ha pupuk kandang, D = Jarak tanam $75 \times 40 \mathrm{~cm}+2 \mathrm{t} / \mathrm{ha}$ pupuk kandang, $\mathrm{E}=$ Jarak tanam $75 \times 40 \mathrm{~cm}+1$ t/ha pupuk kandang, $\mathrm{F}=$ Jarak tanam $75 \times 40$ $\mathrm{cm}+3 \mathrm{t} /$ ha pupuk kandang, $\mathrm{G}=$ Jarak tanam 80 x $20 \mathrm{~cm}+2 \mathrm{t} /$ ha pupuk kandang, $\mathrm{H}=$ Jarak tanam $80 \times 20 \mathrm{~cm}+1 \mathrm{t} /$ ha pupuk kandang, $\mathrm{I}=$ Jarak tanam $80 \times 20 \mathrm{~cm}+3 \mathrm{t} /$ ha pupuk kandang. Pengujian hipotesis pertama menggunakan uji Fhit dengan taraf nyata $5 \%$ apabila hasil ujinya nyata, maka dilanjutkan dengan uji antar perlakuan melalui uji jarak berganda Duncan pada taraf $5 \%$.

Pelaksanaan percobaan dilakukan dengan beberapa tahap yaitu terdiri dari persiapan lahan, aplikasi perlakuan, penanaman, pemupukan, pemeliharaan, dan pemanenan. Pengamatan yang dilakukan meliputi pengamatan penunjang dan pengamatan utama terhadap pertumbuhan tanaman. Komponen hasil, dan hasil tanaman jagung.

Pengamatan penunjang tidak dianalisis secara statistik dan meliputi: analisis tanah sebelum percobaan, keadaan lingkungan, tingkat serangan hama, penyakit, dan gulma yang tumbuh, serta umur berbunga dan umur panen jagung. Pengamatan utama meliputi pertumbuhan tanaman (tinggi tanaman dan Indeks Luas Daun), komponen hasil (panjang tongkol, diameter tongkol, jumlah biji per tongkol, jumlah baris biji per tongkol, dan bobot 100 biji kering) dan hasil tanaman jagung (bobot biji pipilan kering per tanaman, bobot biji pipilan kering per petak, bobot biji pipilan kering per hektar, dan indeks panen).

\section{Hasil dan Pembahasan}

Pengamatan Penunjang Berdasarkan hasil analisis Laboratorium Kesuburan Tanah dan Nutrisi Tanaman Fakultas Pertanian Unpad, tanah ini mengandung pasir $6 \%$, debu $42 \%$, dan liat $52 \%$, sehingga termasuk kriteria tanah liat berdebu. Tanah yang paling ideal untuk tanaman jagung adalah yang bertekstur liat berdebu (Purwono dan Purnamawati, 2007). Tanah ini memiliki pH tanah yaitu 6,12 termasuk agak masam dan memiliki kadar $\mathrm{C} / \mathrm{N}$ ratio yang termasuk karakteristik sedang, yaitu 11,12. Kandungan unsur hara makro N-total 0,17 \% termasuk kategori rendah, $\mathrm{P}_{2} \mathrm{O}_{5}$ 136,77 \% termasuk kategori sangat tinggi, dan $\mathrm{K}_{2} \mathrm{O}$ 68,33\% termasuk kategori sangat tinggi.

Menurut hasil analisis Stasiun Pengamat Dirgantara Pusat Pemanfaatan Sain dan Antariksa LAPAN Tanjungsari (2013) jumlah curah hujan di Jatinangor selama percobaan berkisar antara 149,5 - 358,5 mm. Rata-rata suhu harian selama percobaan berlangsung berkisar antara $22,23-26,47^{\circ} \mathrm{C}$. Selama percobaan ratarata kelembaban nisbi berkisar 89 - 92,6 \%.

Hama yang menyerang selama percobaan antara lain adalah belalang (Valanga nigricornis Burn.) dan hama ulat penggulung daun atau biasa juga disebut ulat pelipat daun (Cnaphalocrosis medinalis Guen.) keduanya menyerang tanaman pada saat 3-7 MST. Larva kumbang tanduk (Chalcosoma atlas) atau biasa disebut ku'uk dan uret, juga merupakan salah satu hama yang menyerang pada percobaan ini. Larva ini banyak ditemukan di dalam tanah dekat perakaran jagung dan memakan akar serta pangkal batang tanaman.

Penyakit yang menyerang selama masa percobaan adalah penyakit karat (Pucciniashorgi) dan hawar daun jagung (Helminthosporiumturticum). Gulma yang menyerang selama percobaan tidak terlalu banyak dan tidak terlalu mempengaruhi tanaman jagung. Gulma yang muncul adalah kecambah kemiri (Aleuritesmoluccana), hal ini disebabkan sebelum ditanami jagung, lahan ini terdapat pohon kemiri yang akhirnya ditebang jauh sebelum pembukaan 
dan persiapan lahan. Selain itu, terdapat pula gulma dominan pada percobaan ini yaitu rumput teki (Cyperusrotundus), putri malu (Mimosa pudica), dan babandotan (Ageratum conyzoides).

Pada percobaan ini, tanaman jagung mulai berbunga pada 9 MST dan seluruh tanaman sudah berbunga seluruhnya pada 11 MST serta panen dilakukan pada saat tanaman jagung berumur 108 HST. Hal ini menunjukkan panen dilakukan pada waktu yang tepat dan masa generatif tanaman sesuai dengan deskripsi.

\section{Pengamatan Utama}

Tinggi Tanaman. Berdasarkan Tabel 1, tinggi tanaman jagung pada 4, 6, dan 8 MST menunjukkan pengaruh yang tidak berbeda nyata dari semua perlakuan.

Tabel 1. Pengaruh Jarak Tanam Berbeda pada Berbagai Dosis Pupuk Organik terhadap Tinggi Tanaman Jagung pada 4, 6, dan 8 MST.

\begin{tabular}{cccc}
\hline \hline Perlakuan & 4 MST & 6 MST & 8 MST \\
\hline A & $73,95 \mathrm{a}$ & $153,50 \mathrm{a}$ & $218,29 \mathrm{a}$ \\
B & $82,49 \mathrm{a}$ & $160,90 \mathrm{a}$ & $221,87 \mathrm{a}$ \\
C & $80,79 \mathrm{a}$ & $167,40 \mathrm{a}$ & $229,33 \mathrm{a}$ \\
D & $85,48 \mathrm{a}$ & $170,81 \mathrm{a}$ & $236,04 \mathrm{a}$ \\
E & $78,47 \mathrm{a}$ & $148,83 \mathrm{a}$ & $206,07 \mathrm{a}$ \\
F & $83,23 \mathrm{a}$ & $164,11 \mathrm{a}$ & $228,92 \mathrm{a}$ \\
G & $82,27 \mathrm{a}$ & $158,60 \mathrm{a}$ & $221,01 \mathrm{a}$ \\
H & $76,33 \mathrm{a}$ & $156,33 \mathrm{a}$ & $219,96 \mathrm{a}$ \\
I & $77,54 \mathrm{a}$ & $160,50 \mathrm{a}$ & $223,04 \mathrm{a}$ \\
\hline \hline
\end{tabular}

Keterangan : Nilai rata-rata yang diikuti huruf yang sama pada kolom yang sama tidak berbeda nyata menurut Uji Jarak Duncan pada taraf 5\%

Perlakuan D (jarak tanam $75 \times 40 \mathrm{~cm}+2$ $\mathrm{t} /$ ha pupuk kandang) memiliki kecenderungan tinggi tanaman yang lebih tinggi bila dibandingkan perlakuan lainnya, yaitu mencapai 236,04 cm. Hal ini menunjukkan bahwa pertumbuhan sudah cukup baik jika dibandingkan dengan deskripsi jagung hibrida P-12 yang hanya mencapai $\pm 211 \mathrm{~cm}$.

Menurut Kuyik dkk. (2012), fotosintesis adalah proses dasar pada tanaman untuk menghasilkan makanan. Makanan yang dihasilkan akan menentukan ketersediaan energi untuk pertumbuhan dan perkembangan tanaman. Cahaya merupakan faktor penting terhadap berlangsungnya fotosintesis, sementara fotosintesis merupakan proses yang menjadi kunci dapat berlangsungnya proses metabolisme yang lain di dalam tanaman.
Indeks Luas Daun. Indeks Luas Daun (ILD) merupakan parameter yang menunjukkan potensi tanaman dalam melakukan fotosintesis yang secara langsung mempengaruhi pertumbuhan dan perkembangan tanaman. Pada daun yang lebih luas, maka lebih maksimal pula penyerapan cahayanya.

Tabel 2. Pengaruh Jarak Tanam Berbeda pada Berbagai Dosis Pupuk Organik terhadap Indeks Luas Daun.

\begin{tabular}{cc}
\hline \hline Perlakuan & Indeks Luas Daun (ILD) \\
\hline A & $5,05 \mathrm{bc}$ \\
B & $4,88 \mathrm{~b}$ \\
C & $4,98 \mathrm{bc}$ \\
D & $3,21 \mathrm{a}$ \\
E & $3,00 \mathrm{a}$ \\
F & $2,98 \mathrm{a}$ \\
G & $5,28 \mathrm{bc}$ \\
H & $5,58 \mathrm{bc}$ \\
I & $6,18 \mathrm{c}$ \\
\hline \hline
\end{tabular}

Keterangan : Nilai rata-rata yang diikuti huruf yang sama pada kolom yang sama tidak berbeda nyata menurut Uji Jarak Duncan pada taraf 5\%

Menurut Gardner dan Pearce (1991) kisaran indeks luas daun yang optimal bagi tanaman budidaya antara lain 3 sampai 5. Pada percobaan ini, indeks luas daun terendah terdapat pada perlakuan D, E, dan F. Ketiga perlakuan ini menggunakan perlakuan jarak tanam yang samayaitu $75 \times 40 \mathrm{~cm}$. Hal ini menunjukkan bahwa pada jarak tanam 75 × 40 $\mathrm{cm}$ dengan dosis pupuk kandang mana pun tidak memberikan hasil yang baik pada indeks luas daun.

Indeks luas daun tertinggi terdapat pada perlakuan I yaitu dengan indeks luas daun mencapai 6,18 yaitu diatas indeks luas daun tanaman budidaya pada umumnya. Perlakuan I menggunakan jarak tanam $80 \times 20 \mathrm{~cm}$ dengan pemberian dosis pupuk kandang $3 \mathrm{t} / \mathrm{ha}$. Hasil penelitian menunjukkan bahwa jarak tanam yang lebih sempit, yaitu jarak tanam $80 \times 20 \mathrm{~cm}$ memberikan indeks luas daun lebih tinggi dibandingkan yang lainnya.

Menurut Goldsworthy dan Fischer (1992) yang dikutip Agrita (2012), faktor yang dapat mempengaruhi besarnya indeks luas daun antara lain adalah jarak tanam dan penyediaan unsur hara nitrogen. Jarak tanam secara langsung dapat mempengaruhi kerapatan populasi suatu tanaman. Nitrogen adalah salah satu unsur hara makro esensial bagi tanaman

Wahyudin, dkk: Pengaruh jarak tanam berbeda pada berbagai dosis pupuk organik terhadap pertumbuhan dan hasil jagung hibrida P-12 di Jatinangor 
yang diperlukan dalam pembentukan dan pertumbuhan vegetatif tanaman dan sebagai bahan dasar penyusunan protein serta pembentukan klorofil. Pupuk kandang domba mengandung unsur $\mathrm{N}, \mathrm{K}$, dan $\mathrm{Ca}$ yang lebih tinggi dibanding bahan organik lainnya (Las dan Setyorini, 2010).

Panjang dan Diameter Tongkol Per Tanaman. Berdasarkan Tabel 3, panjang tongkol dan diameter tongkol tanaman jagung menunjukkan pengaruh yang tidak berbeda nyata dari semua perlakuan. Pada percobaan ini, panjang tongkol memiliki rata-rata yang hampir seragam yaitu berkisar antara $20-21 \mathrm{~cm}$.

Diameter tongkol per tanaman juga memiliki rata-rata yang hampir seragam yaitu berkisar 4,4-4,6 cm. Pada percobaan ini mayoritas tongkol terbentuk sempurna, akan tetapi terdapat sebagian kecil yang kurang terbentuk sempurna.

Pembentukan tongkol merupakan salah satu tahap penting dalam hasil tanaman jagung. Berdasarkan penelitian Adisarwanto (1999) yang dikutip Suhendar (2011) pembentukan tongkol yang kurang atau tidak sempurna dapat disebabkan oleh kurangnya unsur P. Pembentukan tongkol tidak sempurna bisa mengakibatkan tongkol yang berukuran kecil, barisan biji tidak beraturan serta biji kurang berisi. Pembentukan tongkol dapat mempengaruhi produksi jagung yang berupa pipilan kering.

Tabel 3. Pengaruh Jarak Tanam Berbeda pada Berbagai Dosis Pupuk Organik terhadap Panjang Tongkol dan Diameter Tongkol Per Tanaman.

\begin{tabular}{ccc}
\hline \hline Perlakuan & $\begin{array}{c}\text { Panjang } \\
\text { Tongkol }\end{array}$ & $\begin{array}{c}\text { Diameter } \\
\text { Tongkol }\end{array}$ \\
\hline A & $21,26 \mathrm{a}$ & $4,69 \mathrm{a}$ \\
B & $20,45 \mathrm{a}$ & $4,63 \mathrm{a}$ \\
C & $21,24 \mathrm{a}$ & $4,66 \mathrm{a}$ \\
D & $21,73 \mathrm{a}$ & $4,60 \mathrm{a}$ \\
E & $21,02 \mathrm{a}$ & $4,55 \mathrm{a}$ \\
F & $21,94 \mathrm{a}$ & $4,61 \mathrm{a}$ \\
G & $20,87 \mathrm{a}$ & $4,58 \mathrm{a}$ \\
H & $20,53 \mathrm{a}$ & $4,48 \mathrm{a}$ \\
I & $21,63 \mathrm{a}$ & $4,60 \mathrm{a}$ \\
\hline \hline
\end{tabular}

Keterangan : Nilai rata-rata yang diikuti huruf yang sama pada kolom yang sama tidak berbeda nyata menurut Uji Jarak Duncan pada taraf 5\%

Menurut Suhendar (2011), fungsi P bagi tanaman sangat berguna bagi pembentukan biji dan dapat merangsang pertumbuhan akar yang berperan penting dalam penyerapan air dan unsur hara itu sendiri. Unsur $\mathrm{P}$ sangat dibutuhkan sejak awal pertumbuhan, yaitu pada fase vegetatif bahkan hingga fase generatif.

Jumlah Biji Per Tongkol dan Jumlah Baris Biji Per Tongkol. Pada percobaan ini, seluruh perlakuan mencapai kriteria yang baik dalam jumlah baris biji per tongkol, yaitu dengan kisaran 14 samapai 15 baris. Perlakuan yang terbaik pada percobaan ini adalah pada perlakuan C, yaitu jarak tanam $75 \times 25 \mathrm{~cm}+3$ t/ha pupuk kandang. Jarak tanam pada perlakuan ini merupakan jarak tanam anjuran Balai Tanaman Serealia. Melihat hasil terendah dan tertinggi jumlah baris, maka dosis pupuk kandang tidak terlalu berpengaruh, tetapi jarak tanam yang berperan dalam kerapatan populasi dan kompetisi antar tanaman.

Gardner dan Pearce (1991) mengemukakan bahwa unsur P merupakan komponen penting penyusun senyawa untuk transfer energi (ATP dan nukleoprotein), informasi genetik (RNA dan DNA), membran sel, dan fosfoprotein. Hal ini juga dipertegas oleh Poerwowidodo (1993) bahwa kekurangan unsur $\mathrm{P}$ menjadikan tanaman tidak dapat bereproduksi secara normal.

Tabel 4. Pengaruh Jarak Tanam Berbeda pada Berbagai Dosis Pupuk Organik terhadap Jumlah Biji Per Tongkol dan Jumlah Baris Biji Per Tongkol.

\begin{tabular}{ccc}
\hline \hline Perlakuan & $\begin{array}{c}\text { Jumlah Biji } \\
\text { Per Tongkol }\end{array}$ & $\begin{array}{c}\text { Jumlah Baris } \\
\text { Biji Per Tongkol }\end{array}$ \\
\hline $\mathrm{A}$ & $467,90 \mathrm{a}$ & $14,62 \mathrm{ab}$ \\
$\mathrm{B}$ & $443,43 \mathrm{a}$ & $14,62 \mathrm{ab}$ \\
$\mathrm{C}$ & $463,05 \mathrm{a}$ & $15,24 \mathrm{~b}$ \\
$\mathrm{D}$ & $467,01 \mathrm{a}$ & $14,54 \mathrm{ab}$ \\
$\mathrm{E}$ & $441,27 \mathrm{a}$ & $14,46 \mathrm{ab}$ \\
$\mathrm{F}$ & $470,69 \mathrm{a}$ & $14,13 \mathrm{a}$ \\
$\mathrm{G}$ & $434,63 \mathrm{a}$ & $14,63 \mathrm{ab}$ \\
$\mathrm{H}$ & $422,17 \mathrm{a}$ & $14,54 \mathrm{ab}$ \\
$\mathrm{I}$ & $455,13 \mathrm{a}$ & $14,71 \mathrm{ab}$ \\
\hline \hline
\end{tabular}

Keterangan : Nilai rata-rata yang diikuti huruf yang sama pada kolom yang sama tidak berbeda nyata menurut Uji Jarak Duncan pada taraf 5\%

Menurut Pracaya (2008) secara visual defisinsi unsur $\mathrm{P}$ dapat terlihat dari gejala daun yang berwarna biru tua hingga keunguan. Pada penelitian ini, tanaman menunjukkan daun yang berwarna keunguan tetapi hanya terdapat satu gejala pada satu tanaman yang terdapat pada perlakuan jarak tanam $80 \times 20 \mathrm{~cm}+1 \mathrm{t} / \mathrm{ha}$ pupuk kandang. Gejala defisiensi unsur $\mathrm{P}$ yang hanya terdapat pada satu tanaman tidak mempengaruhi hasil tanaman. 
Bobot 100 Kering Biji. Berdasarkan Tabel 5, bobot 100 biji menunjukkan pengaruh yang tidak berbeda nyata dari semua perlakuan. Bobot 100 biji kering pada percobaan kali ini berkisar antara 25-28 g, sedangkan menurut deskripsi Jagung hibrida P-12, kisaran bobot 100 biji kering $\pm 28,9 \mathrm{~g}$.

Tabel 5. Pengaruh Jarak Tanam Berbeda pada Berbagai Dosis Pupuk Organik terhadap Bobot 100 Biji Kering (g).

\begin{tabular}{cc}
\hline \hline Perlakuan & Bobot 100 Biji Kering $(\mathrm{g})$ \\
\hline A & $27,47 \mathrm{a}$ \\
B & $27,20 \mathrm{a}$ \\
C & $26,47 \mathrm{a}$ \\
D & $25,63 \mathrm{a}$ \\
E & $27,33 \mathrm{a}$ \\
F & $27,50 \mathrm{a}$ \\
G & $25,43 \mathrm{a}$ \\
H & $25,47 \mathrm{a}$ \\
I & $28,00 \mathrm{a}$ \\
\hline \hline
\end{tabular}

Keterangan : Nilai rata-rata yang diikuti huruf yang sama pada kolom yang sama tidak berbeda nyata menurut Uji Jarak Duncan pada taraf 5\%

Bobot 100 biji kering secara tidak langsung dapat mempengaruhi hasil tanaman berupa bobot kering. Bobot 100 biji merupakan parameter yang menunjukkan besar endosperm pada biji. Endosperm adalah bagian terbesar dari biji yang merupakan tempat menyimpan cadangan makanan (Kusnadi, 2000).

Menurut Agrita (2012) komponen bobot 100 biji juga dapat dipengaruhi oleh faktor genotip dan lingkungan. Ukuran biji maksimum dapat tercapai pada suhu rata-rata $25^{\circ} \mathrm{C}$. Pada penelitian ini yang berlangsung mulai bulan Maret-Juli 2013, saat pengisian biji (bulan Juni-Juli), suhu rata-rata berada dibawah $25^{\circ} \mathrm{C}$ yaitu kisaran $23,7-24,5^{\circ} \mathrm{C}$. Gardner dan Pearce (1991) mengemukakan bahwa menurunnya persediaan air bagi tanaman jagung pada tiga minggu setelah penyerbukan dapat mempengaruhi jumlah biji dan menurunkan bobot biji.

Bobot Biji Pipilan Kering per Tanaman, Bobot Biji Pipilan Kering per Petak, dan Bobot Biji Pipilan Kering per Hektar.Berdasarkan Tabel 6, hasil percobaan ini tidak memberikan hasil yang berbeda nyata pada semua perlakuan. Pada parameter bobot biji pipilan keringper petak $\left(\mathrm{kg} / \mathrm{m}^{2}\right)$ dan bobot biji pipilan kering per hektar ( $\mathrm{t} / \mathrm{ha})$, menunjukkan bahwa hasil terendah adalah perlakuan $\mathrm{C}$, yaitu perlakuan yang menggunakan jarak tanam $75 \times 25 \mathrm{~cm}$ dengan pemberian dosis pupuk kandang sebesar 3t/ha. Sedangkan hasil terbaik terdapat pada perlakuan B, yaitu perlakuan yang menggunakan jarak tanam $75 \times 25 \mathrm{~cm}$ dengan pemberian pupuk kandang sebesar $1 \mathrm{t} / \mathrm{ha}$

Tabel 6. Pengaruh Jarak Tanam Berbeda pada Berbagai Dosis Pupuk Organik terhadap Bobot Biji Pipilan Kering per Tanaman, Bobot Biji Pipilan Kering per Petak, Bobot Biji Pipilan Kering per Hektar.

\begin{tabular}{cccc}
\hline \hline & \multicolumn{3}{c}{ Bobot Biji Pipilan Kering } \\
\cline { 2 - 4 } Perlakuan & $\begin{array}{c}\text { per } \\
\text { Tanaman } \\
(\mathrm{g})\end{array}$ & $\begin{array}{c}\text { per Petak } \\
\mathbf{( k g )}\end{array}$ & $\begin{array}{c}\text { per } \\
\text { Hektar } \\
\text { (Ton) }\end{array}$ \\
\hline $\mathrm{A}$ & $122,09 \mathrm{a}$ & $8,40 \mathrm{ab}$ & $7,00 \mathrm{ab}$ \\
$\mathrm{B}$ & $117,83 \mathrm{a}$ & $9,19 \mathrm{~b}$ & $7,66 \mathrm{~b}$ \\
$\mathrm{C}$ & $119,10 \mathrm{a}$ & $7,83 \mathrm{a}$ & $6,53 \mathrm{a}$ \\
$\mathrm{D}$ & $113,10 \mathrm{a}$ & $8,70 \mathrm{ab}$ & $7,25 \mathrm{ab}$ \\
$\mathrm{E}$ & $112,73 \mathrm{a}$ & $8,62 \mathrm{ab}$ & $7,18 \mathrm{ab}$ \\
$\mathrm{F}$ & $122,40 \mathrm{a}$ & $8,51 \mathrm{ab}$ & $7,09 \mathrm{ab}$ \\
$\mathrm{G}$ & $112,69 \mathrm{a}$ & $9,30 \mathrm{~b}$ & $7,75 \mathrm{~b}$ \\
$\mathrm{H}$ & $99,08 \mathrm{a}$ & $9,32 \mathrm{~b}$ & $7,76 \mathrm{~b}$ \\
$\mathrm{I}$ & $122,65 \mathrm{a}$ & $9,35 \mathrm{~b}$ & $7,79 \mathrm{~b}$ \\
\hline \hline
\end{tabular}

Keterangan : Nilai rata-rata yang diikuti huruf yang sama pada kolom yang sama tidak berbeda nyata menurut Uji Jarak Duncan pada taraf 5\%

Menurut Soepardi (1983) dikutip Agrita (2012), defisiensi unsur hara dapat mengakibatkan pertumbuahan dan perkembangan tanaman menjadi terganggu, hingga mempengaruhi ukuran biji menjadi lebih kecil yang berakibat pada bobot 100 biji dan bobot biji pipilan kering per tanaman. Defisiensi unsur hara N pada masa vegetatif dapat mempengaruhi kemampuan tanaman untuk menyerap unsur P (Pracaya, 2008).

Rata-rata hasil produksi jagung hibrida P12 menurut deskripsi adalah 8,1 t/ha, sedangkan menurut hasil penelitian ini didapatkan rata-rata tertinggi pipilan kering sebesar 7,79 t/ha. Hasil pipilan kering yang tidaksesuaideskripsi ini berkaitan dengan rendahnya bobot 100 biji yang diakibatkan oleh kurangnya asupan $\mathrm{P}$ dari pupuk kandang domba yang memiliki kandungan $P$ rendah.

Indeks Panen. Pada parameter indeks panen yang terlampir pada Tabel 7, menunjukkan bahwa hasil terendah adalah perlakuan $\mathrm{H}$, yaitu perlakuan yang menggunakan jarak tanam $80 \times 20 \mathrm{~cm}$ dengan pemberian dosis pupuk kandang sebesar $1 \mathrm{t} /$ ha. Sedangkan hasil terbaik terdapat pada perlakuan A, yaitu

Wahyudin, dkk: Pengaruh jarak tanam berbeda pada berbagai dosis pupuk organik terhadap pertumbuhan dan hasil jagung hibrida P-12 di Jatinangor 
perlakuan yang menggunakan jarak tanam $75 \mathrm{x}$ $25 \mathrm{~cm}$ dengan pemberian pupuk kandang sebesar $2 \mathrm{t} /$ ha.

Indeks panen adalah rasio hasil bobot kering biji dengan hasil bobot kering total tanaman. Menurut Goldsworthy dan Fisher (1992) nilai indeks panen optimal dapat bervariasi dari 0,15 samapai 0,52 dan nilai indeks panen dapat dipengaruhi oleh lama dan laju pertumbuhan. Berdasarkan hasil penelitian Balai Penelitian Tanaman Pangan Bogor (Suhendar, 2011), nilai indeks panen untuk tanaman jagung pada daerah tropis sekitar 0,39. Besar nilai indeks panen dapat ditentukan oleh indeks luas daun, bobot 100 biji, dan total hasil pipilan kering.

Tabel 7. Pengaruh Jarak Tanam Berbeda pada Berbagai Dosis Pupuk Organik terhadap Indeks Panen.

\begin{tabular}{cc}
\hline \hline Perlakuan & Indeks Panen \\
\hline A & $0,36 \mathrm{~b}$ \\
B & $0,33 \mathrm{ab}$ \\
C & $0,32 \mathrm{ab}$ \\
$\mathrm{D}$ & $0,31 \mathrm{ab}$ \\
$\mathrm{E}$ & $0,35 \mathrm{ab}$ \\
$\mathrm{F}$ & $0,31 \mathrm{ab}$ \\
$\mathrm{G}$ & $0,31 \mathrm{ab}$ \\
$\mathrm{H}$ & $0,29 \mathrm{a}$ \\
$\mathrm{I}$ & $0,32 \mathrm{ab}$ \\
\hline \hline
\end{tabular}

Keterangan : Nilai rata-rata yang diikuti huruf yang sama pada kolom yang sama tidak berbeda nyata menurut Uji Jarak Duncan pada taraf 5\%

Hasil penelitian pada semua perlakuan menunjukkan hasil dibawah kisaran indeks panen. Hal ini disebabkan oleh bobot 100 biji yang rendah hingga mempengaruhi rasio bobot biji dan total bobot kering tanaman.

\section{Kesimpulan dan Saran}

\section{Kesimpulan}

1. Pemberian berbagai dosis pupuk kandang domba pada jarak tanam berbeda memberikan pengaruh terhadap Indeks Luas Daun, Jumlah Baris Biji per tongkol, Bobot biji pipilan kering per petak, bobot biji pipilan kering per hektar, dan Indeks Panen

2. Perlakuan dengan jarak tanam $75 \times 25 \mathrm{~cm}+$ $1 \mathrm{t} /$ ha pupuk kandang memberikan hasil yang lebih baik dari perlakuan $75 \times 25 \mathrm{~cm}+$ $3 \mathrm{t} /$ ha pupuk kandang, yaitu 7,66 t/ ha.

\section{Saran}

1. Analisis tanah sebaiknya dilakukan sebelum dan setelah percobaan agar mendapatkan informasi lebih lengkap mengenai kriteria dan perubahan kandungan tanah sebelum dan sesudah percobaan.

2. Untuk mendapatkan hasil yang lebih baik, pemberian pupuk kandang diinkubasi terlebih dahulu sebelum diaplikasikan.

\section{Ucapan Terima Kasih}

Penelitian ini dibiayai oleh Lembaga Penelitian dan Pengabdian Kepada Masyarakat Universitas Padjadjaran Bandung dalam skema Hibah Kompetitif Unpad tahun 2013.

\section{Daftar Pustaka}

Adianto. 1993. Biologi Pertanian (Pupuk Kandang, Pupuk Organik Nabati, dan Insektisida). Edisi kedua. Alumni: Bandung.

Agrita, Dita Arpila. 2012. Pengaruh Kombinasi Dosis Pupuk Fosfat dengan Pupuk Kotoran Ayam terhadap Pertumbuhan dan Hasil Tanaman Jagung (Zea mays L.) Hibrida Varietas Bisi-2 pada Inceptisol Jatinangor. Sumedang

Bakhri, Syamsul. 2007. Petunjuk Teknis Budidaya Jagung dengan Konsep Pengelolaan Tanaman Terpadu. Balai Pengkajian Teknologi Pertanian Sulawesi Tengah. Departemen Pertanian.

Balai Penelitian Tanaman Serealia. 2014. Data Statistik Volume Impor Beberapa Komoditas Tanaman Pangan, 2011-2013. Pusat Data dan Informasi Pertanian. Departemen Pertanian. dalam http://aplikasi.deptan. go.id/eksim2011-2013/imporKomoditi.asp Diakses 13 Februari 2014

Balai Penelitian Ternak. 2010. Kandungan Unsur Hara Kotoran Hewan. Balitnak. Bogor.

Gardner dan Pearce. 1991. Fisiologi Tanman Budidaya (terjemahan dari Physiology of Crop Plants oleh Herawati Susilo). Universitas Indonesia (UI-Press). Jakarta

Goldsworthy dan Fisher. 1992. Fisiologi Tanaman Budidaya. Tropik (terjemahan 
dari The Physiology of Tropical Field Crops oleh Tohari). Gadjah Mada University Press. Yogyakarta.

Hariyadi, A. 2013. Produksi Jagung P12 dapat menghasilkan 20 ton per Ha, hentikan impor. dalam http://cybex.deptan.go.id/ penyuluhan/produksi-jagung-p12-dapatmenghasilkan-20-ton-hahentikan-impor diakses pada 10 April 2013. Badan Penyuluhan dan Pengembangan Sumber Daya Manusia Pertanian. Kementrian Pertanian.

Kusnadi, M.H. 2000. Kamus Istilah Pertanian. Kanisius. Yogyakarta.

Kuyik, Antonius R., Pemmy Tumewu, D.M.F. Sumampow, dan E.G. Tulungen. 2012. Respons Tanaman Jagung Manis (Zea mays saccharata L.) Terhadap Pemberian Pupuk Organik. Fakultas Pertanian Universitas Sam Ratulangi. Manado.

Las, I. dan D. Setyorini. 2010. Kondisi Lahan, Teknologi, Arah, dan Pengembangan Pupuk Majemuk NPK dan Pupuk Organik. Hlm 47. Dalam Prosiding Semnas Peranan Pupuk NPK dan Organik dalam Meningkatkan Produksi dan Swasembada Beras Berkelanjutan. Balai Besar Litbang Sumberdaya Lahan Pertanian, Bogor 24 Februari 2010.

Oldeman, L. R. 1975. An Agroclimate Map of Java.
Contr. Centr. Res. Inc. Agr.Bogor No. 17.

Purwono dan Heni Purnamawati. 2007. Budidaya Tanaman Pangan. Agromedia. Jakarta.

Poerwowidodo. 1993. Telaah Kesuburan Tanah. Angkasa. Bandung

Pracaya. 2008. Hama dan Penyakit Tanaman hal: 394-396. Penebar Swadaya. Jakarta

Pusat Penelitian dan Pengembangan Tanaman Pangan. 2012. Deskripsi Varietas Unggul Jagung. Badan Penelitian dan Pengembangan Tanaman Pertanian. Kementan.

Stasiun Pengamat Dirgantara Pusat Pemanfaatan Sain dan Antariksa LAPAN Tanjungsari. 2013. Data Curah Hujan Tahun 2003-2012 di Kebun Percobaan Fakultas Pertanian Universitas Padjadjaran. Sumedang

Suhendar, Deden. 2011. Pengaruh Dosis Pupuk $\mathrm{N}, \mathrm{P}, \mathrm{K}$ dan Jenis Pupuk Organik terhadap Pertumbuhan dan Hasil Tanaman Jagung (Zea mays L.) Hibrida P-12 di Jatinangor. Sumedang

Sutanto, R. 2002. Pertanian Organik. Kanisius. Jakarta.

Zubachtirodin, M.S. Pabbage, dan Subandi. 2007. Wilayah Produksi dan Potensi Pengembangan Jagung. Balai Penelitian Tanaman Serealia Maros. Departemen Pertanian. 